\title{
State support to business in agriculture of Ukraine on the basis of sustainability of incomes
}

\section{Prudivus}

\section{National Science Center "Institute of Agrarian Economics"}

The purpose. To assess state of development of business in farming industry of Ukraine and to offer paths of perfecting the gear of its state support on the basis of sustainability of incomes. Methods. Dialectic, abstract-logical and systems analysis (theoretical and methodological generalizations, definition of nature of the gear of state support of business in farming industry on the basis of sustainability of incomes). Results. As novelty aspects they defined notion «the gear of the state support of business in farming industry» as system of legal, organizational and economic instruments and provisions. It promotes development of agricultural business and execution of public functions by it in view of features of reproductive processes depending on seasonal prevalence of production, specificity of use in farming industry of biological organisms, dependences of branch on influence of soil-climatic conditions and external economic factors. Conclusions. To develop the gear of state support to business in farming industry it is necessary by provision of stable monetary-credit policy, accessibility of credit resources, stimulation of banks of commerce to crediting farming industry, use of agricultural insurance and efficient infrastructure of agrarian market. In turn it will promote sustainability of incomes of agricultural commodity producers.

Key words: organizational gear, state support, business, farming industry.

Formulation of the problem. The development of entrepreneurship in agricultural production is able to exert a powerful influence on the positive economic dynamics in Ukraine, and domestic agriculture can become a "locomotive" for modernizing the country, which can create a synergistic effect of the development of the country's economy. In addition, the activity of any enterprise is that its financial results not only cover production costs, but also bring revenues that would allow for an expanded reproduction of its activities. The difficult situation in agriculture of Ukraine shows considerable difficulties in ensuring not only extended but also simple reproduction in this area. In this regard, one of the main problems that need to be solved is ensuring the profitability of agricultural production, through state support, which will facilitate the development of entrepreneurship.

Analysis of recent research and publications. Issues of studying and improving the mechanism of state support of business entities in agricultural production and business development are highlighted in the works of many scholars, including: M. Malik [3], T. Kalashnikova [4], V. Goryovyi [5], P. Sabluk, S. Kvasha, V. Rossokha [6], Yu. Lupenko [7], O. Sharapa, V. Zayats, O. Oliynyk [8], M. Kodyanska [9], A. Yeremeyev, etc. At the same time, the issues of forming the mechanism of state support of entrepreneurship in agricultural production on the basis of income stability are insufficiently highlighted.

The purpose of the article. Assess the state of development of entrepreneurship in agricultural production in Ukraine and propose ways to improve the mechanism of its state support on the basis of the sustainability of incomes.

Presentation of the main research results. Entrepreneurship is the basis of economic and social development, solving social problems, overcoming poverty and ensuring a high standard of living for citizens. The importance of developing the agrarian sector, as one of the foundations of the country's competitiveness on world markets, is mentioned in the annual letters of the President of Ukraine to the Verkhovna Rada of Ukraine "On the Internal and External Situation of Ukraine". However, the 
development of the agrarian sector is not possible without the development of entrepreneurship in agricultural production.

According to the State Statistics Service of Ukraine, as of 11.01.2016 in Ukraine (without taking into account the temporarily occupied territory of the Autonomous Republic of Crimea, Sevastopol and parts of the zone of the anti-terrorist operation), there were 47.7 thousand agricultural enterprises that used 19.8 million hectares of agricultural land including 19.0 million hectares of arable land, of which 33.7 thousand farms cultivated 4.4 million hectares of agricultural land, including 4.2 million hectares of arable land.

Analysis of the dynamics of the number of agricultural enterprises by organizational and legal forms of management as of 01.11 of each year showed that over the past five years the number of active agricultural enterprises has decreased by 1.7 thousand farms, which indicates a negative trend in this area (Table 1).

Table 1. Number of agricultural enterprises by organizational and legal forms of management in 2012-2016*

\begin{tabular}{|c|c|c|c|c|c|c|}
\hline $\begin{array}{l}\text { Agricultural enterprises for } \\
\text { organizational and legal } \\
\text { forms of management }\end{array}$ & 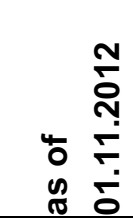 & 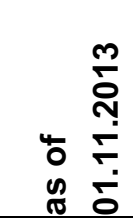 & 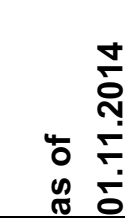 & 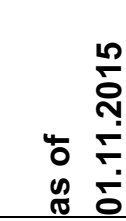 & ț & 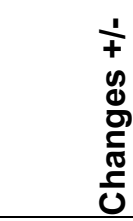 \\
\hline Total & 49415 & 49046 & 46199 & 45379 & 47697 & -1718 \\
\hline Business partnerships & 8235 & 8245 & 7750 & 7721 & $x$ & $x$ \\
\hline Private enterprises & 4220 & 4095 & 3772 & 3627 & $\mathrm{x}$ & $x$ \\
\hline Farms & 34035 & 34168 & 33084 & 32303 & 33682 & -353 \\
\hline State enterprises & 296 & 269 & 228 & 241 & $x$ & $x$ \\
\hline $\begin{array}{l}\text { Enterprises of other forms of } \\
\text { management }\end{array}$ & 1781 & 1460 & 691 & 891 & $\mathrm{x}$ & $\mathrm{x}$ \\
\hline Cooperatives & 848 & 809 & 674 & 596 & $x$ & $x$ \\
\hline \multicolumn{7}{|l|}{ Registered: } \\
\hline agricultural production & $x$ & 1193 & 1075 & 997 & 992 & -201 \\
\hline agricultural service & $\mathrm{x}$ & 1015 & 924 & 944 & 1006 & -9 \\
\hline
\end{tabular}

* without taking into account the temporarily occupied territory of the Autonomous Republic of Crimea, the city of Sevastopol and part of the area of the anti-terrorist operation.

Source: Systematized by the author on the basis of data from the State Statistics Service of Ukraine [1].

In addition, in recent years, Ukraine has experienced a sharp decline in the number of small agricultural enterprises due to their transition to the control of powerful agro-industrial formations (Table 2).

Table 2. Number of agricultural enterprises by their size in 2012-2015 *

\begin{tabular}{|l|l|l|l|l|l|}
\hline \multirow{2}{*}{} & \multirow{2}{*}{ Total, units } & \multicolumn{3}{|l|}{ Including } \\
\cline { 3 - 6 } & & $\begin{array}{l}\text { large } \\
\text { enterprises }\end{array}$ & $\begin{array}{l}\text { medium } \\
\text { enterprises }\end{array}$ & $\begin{array}{l}\text { small } \\
\text { businesses }\end{array}$ & $\begin{array}{l}\text { of them } \\
\text { microenterprises }\end{array}$ \\
\hline 2012 & 47656 & 26 & 3143 & 44487 & 39103 \\
\hline 2013 & 49848 & 27 & 2915 & 46906 & 41495 \\
\hline 2014 & 46012 & 28 & 2595 & 43389 & 38430 \\
\hline 2015 & 46744 & 29 & 2533 & 44182 & 39237 \\
\hline Changes $+/-$ & -912 & 3 & -610 & -305 & 134 \\
\hline
\end{tabular}


* without taking into account the temporarily occupied territory of the Autonomous Republic of Crimea, the city of Sevastopol and part of the area of the anti-terrorist operation.

Source: Systematized by the author on the basis of data from the State Statistics Service of Ukraine [1].

The process of consolidation of land banks of agroholdings in Ukraine is constantly ongoing [2]. According to Latifundist.com, a national agroportal, about 20 agroholdings have over 100,000 hectares of land. For example, the 10 largest companies by the end of 2015 carried out their production at an area of 3.0 million hectares, accounting for almost $16 \%$ of all agricultural lands, of which: Ukrlandfarming - 654 thousand hectares (over the past three years, has increased its land bank by 104 thousand hectares of arable land), $\mathrm{NCH}$ Capital - 450 thousand hectares (increased land tenure by 100 thousand hectares), Myronivsky Hliboproduct - 380 thousand hectares (increased land tenure by 100 thousand hectares), Kernel - 390 thousand hectares (increased land tenure by 60 thousand hectares).

However, such consolidation has negative aspects, but in terms of entrepreneurship development, it does not contribute to the creation of a competitive environment. One of the reasons for such a transition of small agricultural enterprises is the practical inability to obtain loans from agricultural enterprises whose cultivation is up to 500 hectares. In addition, the lack of state support in recent years, including which would ensure the sustainability of incomes of agricultural producers.

At the same time, it should be noted that for the analyzed period from 2010 to 2016 , the number of employees in agricultural enterprises decreased by 153.8 thousand people, which indicates an increase in unemployment and the need for state support for the development of small forms of management in agricultural production, in order to increase employment rural population. The situation with employment and employment opportunities in the countryside is considered catastrophic, but there is a significant potential for the development of entrepreneurship in the village in terms of creating new jobs and increasing the number of employed people by creating farms and cooperatives [3].

State support is one of the priority directions of implementation of strategic development and ensuring economic stability of agricultural enterprises; obtaining state support positively affects the economic stability of agricultural enterprises, because it provides the prevailing rates of growth of indicators of production efficiency and reduces their level of fluctuations. [4].

It should be noted that the crisis in agriculture in Ukraine, which we can observe today, is caused by a number of reasons: the deepening of the disparity of prices for agricultural products and products of other industries (the cost of fuel, plant protection products, mineral fertilizers, foreign agricultural machinery in conditions of high-quality domestic analogues ), high risk of economic activity in agricultural production (in particular, dependence on natural and climatic conditions), low turnover of investments in rural economic production of resources (the average of the production cycle is one year), the lack of an efficient infrastructure for the sale of agricultural products (limited access of agricultural producers to the final consumers of products), insecurity of agricultural producers with affordable credit resources (high interest rates on loans and reluctance due to high risks, lending to agricultural production by banking institutions), insecurity from the side fiscal and monetary policies (high inflation, frequent changes in the tax system) and others.

Consequently, the stability of agricultural enterprises' revenues depends on a large number of factors that influence the results of economic activity. We believe that the most significant impact on the sustainability of agricultural incomes is: lack of an effective market; instability of fiscal and monetary policy of the state; insecure banking institutions of agricultural producers with affordable credit resources; distrust of agricultural producers to insurance companies as a consequence of the refusal of manufacturers from insurance services and damage to natural disasters. 
Consequently, the mechanism of state support for entrepreneurship in agricultural production is an integral part of the state regulation mechanism and should be aimed at ensuring the profitability of production at a level sufficient for extended reproduction.

Taking into account our research, we can conclude that "the mechanism of state support for entrepreneurship in agricultural production" is a system of legal, organizational and economic instruments that promote the development of agricultural entrepreneurship and the fulfillment of its social functions, taking into account the peculiarities of the processes of expanded reproduction depending on the seasonality of production , specifics of use in agricultural production of biological organisms, industry dependence on swim soil and climatic conditions and the impact of external economic factors.

The stability of agricultural incomes is an integral indicator that is exposed to many different factors, some of which arise in the environment of the enterprise itself and entirely dependent on its activities, while others are the result of the external environment and the influence of the enterprise on them is very limited, which necessitates the provision of state support on the basis of income sustainability.

In order to build an effective mechanism of state support for entrepreneurship on the basis of income stability, which will provide protection to agricultural producers in the face of globalization and the external influence of world competitors, which is intensifying in connection with European integration processes, more extensive use of foreign and own experience is needed.

The mechanism of state support of entrepreneurship in agricultural production on the basis of the stability of incomes of agricultural producers, is depicted in Fig. 1.

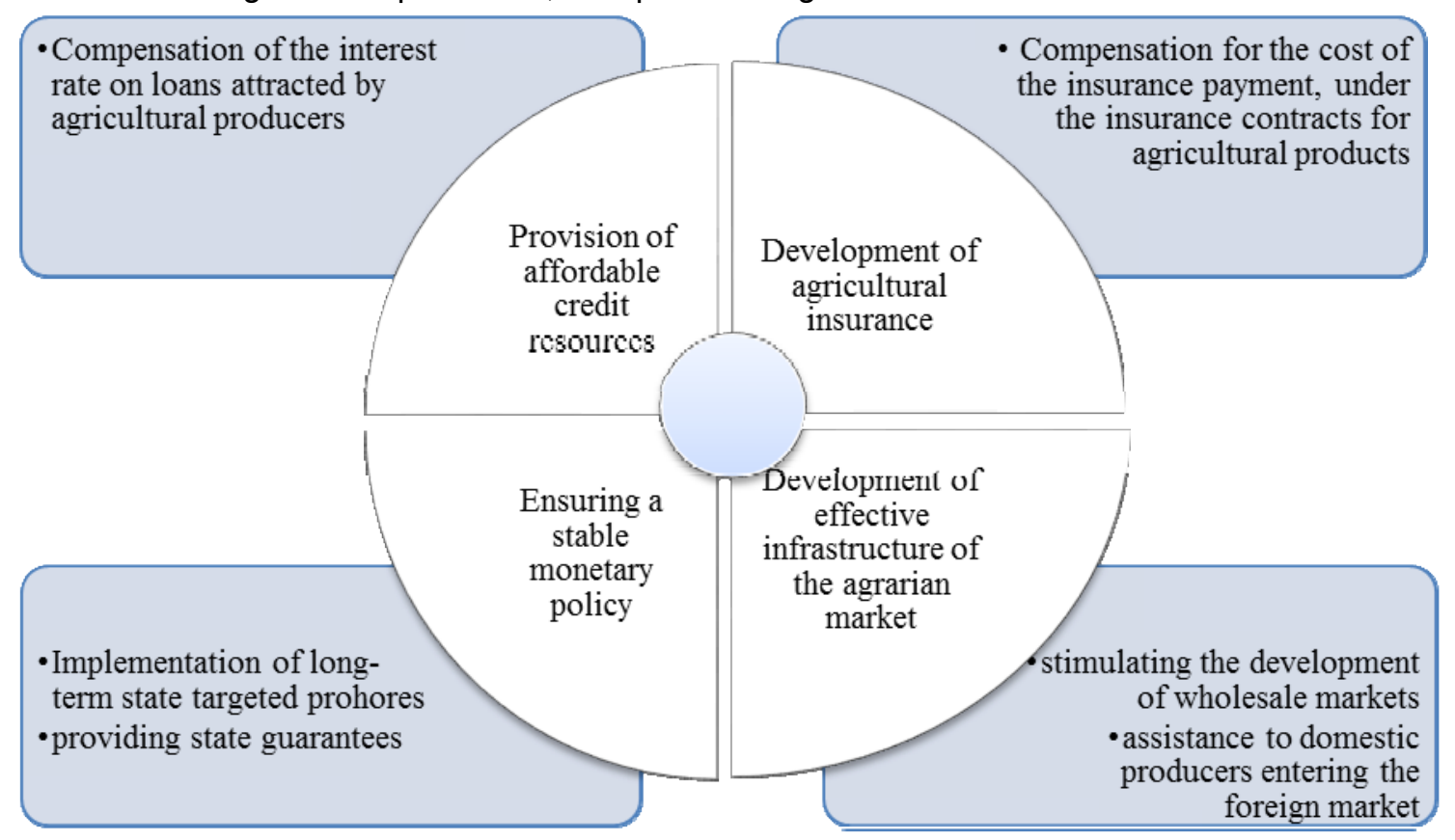

Fig. 1. The mechanism of state support of entrepreneurship in agricultural production on the basis of the stability of incomes of agricultural commodity producers

Source: developed by the author.

In our opinion, the mechanism of state support of entrepreneurship on the basis of income stability, first of all should summarize economic factors, stimulate, effectively operate, promote redistribution of income, provide enhanced reproduction, focus on ensuring higher productivity of production, promote welfare, promote stabilization of food markets, etc. 


\section{Conclusions}

State support for entrepreneurship in agricultural production is one of the components of strategic development and ensuring the sustainability of incomes of agricultural producers. Ensuring state support for entrepreneurship on the basis of income sustainability is extremely important, as well as due to Ukraine's membership in the WTO and the association with the EU, since domestic agricultural producers can be pushed out of the market due to their low competitiveness.

Therefore, to develop the mechanism of state support for entrepreneurship in agricultural production it is necessary: 1) by ensuring stable monetary policy, availability of credit resources, stimulation of commercial banks to lend to agricultural production, development of agricultural insurance and effective infrastructure of the agrarian market, which in turn will be promote the sustainability of incomes of agricultural commodity producers; 2) a significant increase in the number of farms and agricultural cooperatives on the basis of state support for these forms of farming in the countryside.

\section{References}

1. Statistical collection "Agriculture of Ukraine in 2015". Responsible for the issue of O. M. Prokopenko. State Statistics Service of Ukraine, 2016. - 360 p.

2. Demyanenko S. Agroholdings in Ukraine: the process of formation and development // Economy of Ukraine -2009. No. 12. p.51-55.

3. Malik M. Entrepreneurship and development of rural territories / M. I. Malik // Economy of agroindustrial complex. - 2016. - No. 6. - p.97-103.

4. Kalashnikova T. State support in ensuring economic stability of agricultural enterprises / Kalashnikova T.V., Klepcheva O. // Economy of agroindustrial complex. - 2014. - No. 2 - P. 51.

5. Gorovyi V., Zbarskaya A. Development of entrepreneurship in the agrarian sector of the economy of Ukraine [monograph]: ed. professor V. Gorovyi. K: CP "Komprint", 2016. - 360 p.

6. Rossokha $V$. Institutional provision of management of agricultural activities of agrarian enterprises / Rossokha V.V., Sharapa O.M. // Economy of agroindustrial complex. - 2016. - No. 10 - p. 73-83.

7. Strategic directions of development of entrepreneurship and cooperation in agriculture till $2020 /$ [Yu. Lupenko, M. Malik, V. Zayats, etc.]; for ed. M. Malik. - K .: NSC "Institute of Agrarian Economics", 2013. - 50 p.

8. Oliynyk O. Criteria for state support of agricultural enterprises / O.V.Oliynyk, T.V.Kalashnikov // Economy of agroindustrial complex. - 2013. - No. 2. - p.49-53.

9. Kudenska $M$. State support for the development of the agrarian sector of the economy $/$ Kodenska M., Yeremeyeva A. // Economy of the agroindustrial complex. - 2013. - № 6 - P. 14-17.

10. Spector D. «State Aids: Economic Analysis and Practice in the European Union» // Competition Policy in the EU : Fifty Years on from the Treaty of Rome. Oxford University Press. - 2009 _P. 176. 